\title{
Implementasi Program Jaminan Kesehatan Khusus Terpadu dalam Upaya Perlindungan dan Pemenuhan Hak Kesehatan Penyandang Disabilitas
}

\author{
Rut Dwi Ardiyantini ${ }^{1}$
}

\begin{abstract}
Abstrak
Program Jamkesus Terpadu digulirkan oleh Pemerintah Daerah DIY melalui Bapel Jamkesos DIY untuk mewujudkan perlindungan dan pemenuhan hak kesehatan penyandang disabilitas dengan cara mempermudah, mendekatkan, memfasilitasi, dan memberikan jaminan. Penelitian ini bertujuan untuk mengetahui implementasi program tersebut di Kabupaten Gunungkidul. Penelitian ini menggunakan metode kualitatif dengan penekanan pada pendekatan deskriptif. Informan penelitian ini berjumlah 13 orang yang dipilih melalui teknik purposive sampling dan snowball sampling. Teknik pengumpulan data dilakukan dengan wawancara mendalam, observasi, dan dokumentasi. Hasil penelitian menunjukkan bahwa implementasi berdasarkan analisis keluaran program dari tujuh indikator, masih memuat masalah pada lima indikator tersebut yaitu cakupan, frekuensi, bias, ketepatan layanan, dan akuntabilitas. Namun demikian, hasil implementasi juga menunjukkan bahwa program tersebut telah memberikan dampak yang dapat dirasakan manfaatnya secara langsung. Akan tetapi, pada dampak jangka menengah menunjukkan masih belum sepenuhnya bisa dirasakan dan pada dampak jangka panjang juga masih menjadi harapan program untuk ke depannya.
\end{abstract}

Kata kunci: Jamkesus Terpadu, Penyandang Disabilitas, Perlindungan dan Pemenuhan Hak Kesehatan

\begin{abstract}
Jamkesus Terpadu program is launched by the Provincial Government of DIY to realize the protection and fulfillment of health rights for persons with disabilities by making it easier, closer, facilitating, and giving the guarantee. This research aims to know the program's implementation in Gunungkidul Regency. This research used a qualitative method with an emphasis on descriptive approach. There are 13 informants, who were selected through purposive sampling and snowball sampling techniques. Data collection is done through in-depth interview, observation, and documentation. The research result shows that the implementation based on an analysis of the program's output from seven indicators that still contained problems there were five indicators namely coverage, frequency, bias, the accuracy of service, and accountability. Although the outcome of the program shows that the impact of the program can be felt directly. The medium-term impact shows not yet fully felt. Furthermore, the long-term impact is still the expectation of future programs.
\end{abstract}

Keywords: Jamkesus Terpadu, Persons with Disabilities, Protection and Fulfillment of Health Rights

\section{Pendahuluan}

Kesehatan merupakan hak asasi manusia. Sebagai penanggung jawab atas hak asasi manusia, negara juga berkewajiban untuk memenuhi hak-hak kesehatan warganya. Sehubungan dengan itu, sebagian hak tersebut juga telah direalisasikan oleh pemerintah Indonesia melalui program Jaminan Kesehatan Nasional (JKN) sebagai wujud nyata dari Sistem Jaminan Sosial Nasional (SJSN). Di dalam SJSN, ditegaskan bahwa hakikatnya jaminan kesehatan diselenggarakan untuk menjamin terpenuhinya kebutuhan dasar kesehatan bagi setiap warga Indonesia (UU No. 40 Tahun 2004). Hal ini berarti bahwa jaminan kesehatan wajib disediakan oleh negara bagi seluruh warga Indonesia, tidak terkecuali juga bagi penyandang disabilitas, sebab mereka memiliki kedudukan dan hak yang sama sebagai warga negara Indonesia. Hal demikian menjadi wajar mengingat data SUPAS tahun 2015 (BPS 2016), menunjukkan bahwa $8,56 \%$ penduduk Indonesia berusia di atas 10 tahun memiliki kondisi disabilitas atau mengalami gangguan fungsional dan data ini terbatas pada kelompok usia di atas 10 tahun, sedangkan yang berusia di bawah 10 tahun masih tanda tanya. Dapat diduga, jika keduanya diakumulasi maka angka presentasi tersebut niscaya lebih besar.

\footnotetext{
${ }^{1}$ Departemen Pembangunan Sosial dan Kesejahteraan, Universitas Gadjah Mada (email korespondensi: rutdwi1906@gmail.com)
} 
Rut Dwi Ardiyantini - Implementasi Program Jaminan Kesehatan Khusus Terpadu dalam Upaya Perlindungan dan Pemenuhan Hak Kesehatan Penyandang Disabilitas

Lebih lanjut, penyandang disabilitas termasuk salah satu kelompok sosial yang rentan karena terjerat sejumlah persoalan khusus, salah satunya ialah kesulitan di dalam mendapatkan hak-hal sosial bidang kesehatan. Layanan kesehatan khusus dan pembiayaan bagi mereka masih terbatas, rujukan pengobatan yang rumit, dan keterbatasan akses pada transportasi (Kusdiyanto, 2018). Oleh karena itu, penyediaan layanan kesehatan khusus bagi penyandang disabilitas merupakan suatu kebutuhan.

Melihat masalah yang dihadapi oleh penyandang disabilitas tersebut, Pemerintah Provinsi Daerah Istimewa Yogyakarta (DIY) mengupayakan perlindungan dan pemenuhan hak kesehatan melalui Peraturan Daerah (Perda) DIY Nomor 4 Tahun 2012 tentang Perlindungan dan Pemenuhan Hak-Hak Penyandang Disabilitas. Dalam peraturan tersebut, dijelaskan bahwa Pemerintah DIY memberikan jaminan kesehatan melalui penyelenggaraan program Jaminan Kesehatan Khusus (Jamkesus) bagi Penyandang Disabilitas (Pasal 55 ayat 2 dan 3).

Namun demikian, dalam praktiknya, pelaksanaan Jamkesus bagi penyandang disabilitas juga tidak luput dari berbagai persoalan. Sebagaimana Widiyanto (2016) menjelaskan bahwa dari 25.170 orang kepesertaan Jamkesus pada tahun 2015 dan 2016, tercatat hanya kurang dari $10 \%$ yang dapat mengakses layanan Jamkesus tersebut. Rendahnya angka tersebut disinyalir diakibatkan oleh beberapa faktor, seperti validitas kepesertaan, informasi program yang minim, dan penyediaan sarana dan tenaga kesehatan yang belum semua ramah bagi penyandang disabilitas. Hal inilah yang terverifikasi dalam evaluasi program Jamkesus tahun 2013 - 2015 yang menunjukkan bahwa akses Jamkesus masih jauh dari harapan (Kementerian PAN dan RB, 2017). Tidak hanya itu, kerumitan prosedur dan jarak tempuh ke tempat pelayanan yang jauh juga menjadi penghambat aksesibilitas terhadap program ini.

Berangkat dari permasalahan tersebut, Pemerintah DIY menggagas program Jamkesus Disabilitas Terpadu pada bulan November 2015 dengan maksud mempermudah, mendekatkan, memfasilitasi dan memberikan jaminan kepada penyandang disabilitas. Sebagaimana jumlah penyandang disabilitas di DIY pada tahun 2018 adalah sebanyak 29.025 orang dan 1.931 orang di antaranya adalah kategori usia anak- anak. Adapun distribusi jumlah penyandang disabilitas per wilayah di DIY adalah sebagai berikut: Kabupaten Kulon Progo sebanyak 5.571 orang, Kabupaten Bantul 6.770 orang, Kabupaten Gunungkidul 8.226 orang, Kabupaten Sleman 6.506 orang, dan Kota Yogyakarta 1.952 orang (Dinas Sosial DIY, 2019).

Berdasarkan data tersebut, Kabupaten Gunungkidul menjadi daerah dengan jumlah penyandang disabilitas terbanyak di Provinsi DIY. Kabupaten Gunungkidul juga memiliki wilayah yang paling luas, sekitar 46,63\% dari luas wilayah daratan Provinsi DIY, dengan kondisi geografi berupa dataran tinggi yang tidak rata. Kondisi tersebut menunjukkan bahwa medan yang cukup berat dapat menjadi tantangan tersendiri dalam melaksanakan pelayanan Jamkesus Terpadu di Gunungkidul.

Menurut Kepala Dinas Kesehatan DIY, pelaksanaan Jamkesus bagi disabilitas masih mengalami hambatan, di mana tingkat kemanfaatannya masih sangat rendah karena validitas kepesertaan serta prosedur yang rumit bagi disabilitas untuk mendapatkan pelayanan kesehatan (Solider, 2018). Sebagaimana yang tertera pada gambar 1 di bawah ini yang menunjukkan bahwa jumlah fasilitas kesehatan di Kabupaten Gunungkidul pada tahun 2018 berjumlah 271. Rasio fasilitas pelayanan kesehatan dengan penduduk penyandang disabilitas di Kabupaten Gunungkidul ialah 1:30; yang artinya hanya 1 fasilitas kesehatan untuk melayani sebanyak 30 penduduk penyandang disabilitas. Meskipun relatif masih rasional, namun para penyandang disabilitas tetap saja mengalami kesulitan di dalam mobilitasnya untuk mengakses pelayanan kesehatan, karena kondisi geografis yang ada di Kabupaten Gunungkidul.

Dengan demikian, tulisan ini bertujuan untuk melihat bagaimana implementasi pelayanan Jaminan Kesehatan Khusus Terpadu bagi penyandang disabilitas di Kabupaten Gunungkidul, Provinsi DIY. Adapun yang menjadi fokus bahasan pada artikel ini adalah implementasi program Jaminan Kesehatan Khusus Terpadu (selanjutnya disingkat JKT) dalam upaya perlindungan dan pemenuhan hak kesehatan bagi penyandang disabilitas.

\section{Kerangka Teori}

Implementasi diartikan sebagai suatu aktivitas yang dimaksudkan untuk mengoperasionalisasikan sebuah program 
Gambar 1

Jumlah Fasilitas Kesehatan di Kabupaten Gunungkidul Tahun 2018

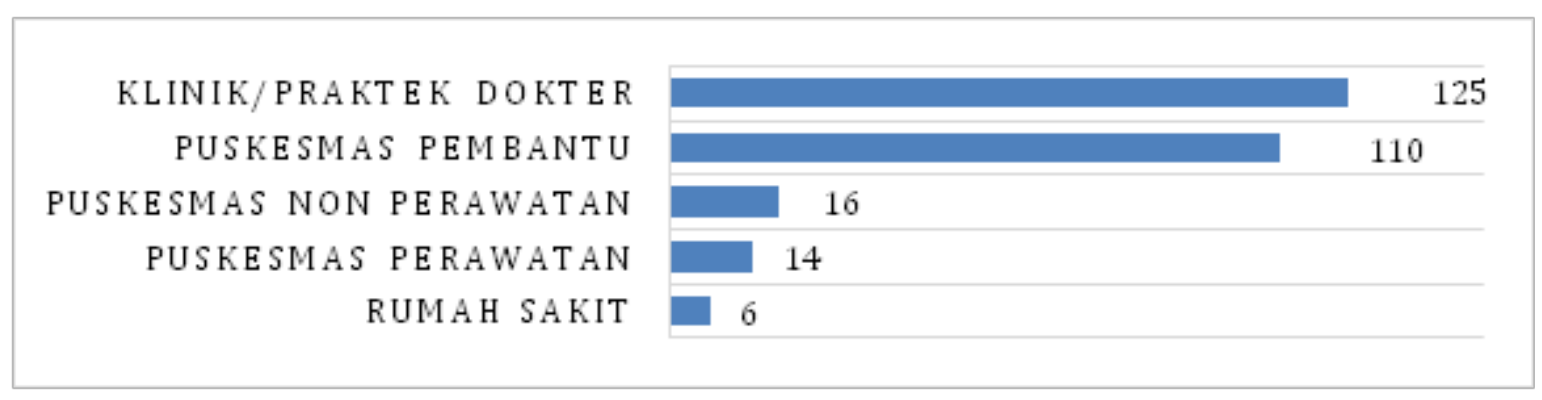

Sumber: Badan Pusat Statistik Kabupaten Gunungkidul, 2019

(Jones dikutip Sidik, 2015: 29) dan berkaitan dengan berbagai kegiatan yang diarahkan pada realisasi program (Gordon dikutip Mulyadi 2015: 24). Para ahli (Crout dan Palmer dikutip Azwar, 1996: 45) mengartikan bahwa program atau kegiatan-kegiatan merupakan sebuah upaya yang terencana, sistematis, dan terpadu yang dipandang perlu untuk dilakukan dalam rangka untuk mencapai tujuan tertentu. Program merupakan interpretasi dari sebuah kebijakan pemerintah yang berisi kumpulan instruksi, yang dibuat untuk memperbaiki permasalahan yang ada. Program harus ada dalam mengimplementasikan suatu kebijakan (Dodi, 2012:15). Sehingga, implementasi program adalah rangkaian kegiatan yang merupakan realisasi dari suatu program secara nyata, terencana, sistematis, dan berkesinambungan yang dilaksanakan untuk mencapai suatu tujuan tertentu dan hasil yang telah ditentukan.

Dalam tulisan ini, implementasi program Jamkesus Terpadu merupakan tahapan kegiatan untuk mendistribusikan keluaran program yang dilakukan oleh pihak pelaksana kepada kelompok sasaran sebagai upaya untuk mewujudkan tujuan program. Implementasi program berkaitan dengan praktik-praktik pelaksanaan program di tengah masyarakat yang secara keseluruhan akan menggambarkan kinerja. Kinerja merujuk pada keluaran, hasil, maupun pencapaian. Terkait dengan kebijakan, kinerja diartikan sebagai gambaran mengenai tingkat pencapaian implementasi dalam mewujudkan sasaran dan tujuan suatu kebijakan, baik berupa keluaran (output) maupun hasil (policy) kebijakan (Sidik, 2015: 30). Kinerja berguna untuk melihat keberhasilan atau kegagalan dari implementasi program melalui suatu pengukuran terhadap kinerja tersebut.
Purwanto dan Sulistyastuti (dikutip oleh Sidik, 2015) menyebutkan bahwa terdapat dua indikator dari luaran tersebut. Pertama, indikator keluaran digunakan untuk mengetahui konsekuensi langsung yang dirasakan oleh kelompok sasaran sebagai akibat dari adanya realisasi kegiatan, aktivitas, distribusi hibah, subsidi, dan lain-lain yang dilaksanakan dalam implementasi. Secara umum, apabila program yang ingin dievaluasi tersebut merupakan kebijakan distributif, kebijakan itu dimaksudkan untuk membantu anggota masyarakat atau kelompok masyarakat yang kurang beruntung melalui instrumen material seperti: pelayanan gratis, subsidi, hibah, dan lain-lain. Berpedoman dari Ripley (1985), indikator yang dapat digunakan untuk menilai kualitas keluaran digambarkan pada Tabel 1.

Kedua, indikator hasil atau dampak, digunakan untuk menilai hasil implementasi suatu program. Indikator ini pada dasarnya berkaitan dengan perubahan kondisi masyarakat yang menjadi kelompok sasaran program yakni kondisi awal yang tidak dikehendaki menuju ke kondisi baru yang dikehendaki. Dampak yang terjadi sangat bergantung pada program yang telah ditetapkan. Penilaian pada hasil program meliputi dampak langsung secara jangka pendek, menengah, dan panjang.

\section{Metode Penelitian}

Penelitian ini menggunakan metode kualitatif dengan penekanan pada pendekatan deskriptif. Metode ini digunakan oleh karena data yang dicari lebih mampu mendeskripsikan dan menjelaskan secara rinci pertanyaan penelitian (Creswell, 2012). Selain itu, penggunaannya juga dimaksudkan untuk mencari fakta-fakta sosial berdasarkan pengalaman subjek penelitian 
Rut Dwi Ardiyantini - Implementasi Program Jaminan Kesehatan Khusus Terpadu dalam Upaya Perlindungan dan Pemenuhan Hak Kesehatan Penyandang Disabilitas

Tabel 1

Indikator Keluaran (Output) Program

\begin{tabular}{|c|c|c|}
\hline No & Aspek Indikator Keluaran & Penjelasan \\
\hline 1 & Akses & $\begin{array}{l}\text { Untuk mengetahui bahwa program atau layanan yang diberikan mudah } \\
\text { dijangkau oleh kelompok sasaran. }\end{array}$ \\
\hline 2 & Cakupan (coverage) & $\begin{array}{l}\text { Untuk menilai seberapa besar kelompoksasaran yang sudah dapat dijangkau } \\
\text { (mendapatkan layanan, hibah, transfer dana, dan sebagainya) dengan } \\
\text { menetapkan siapa saja yang menjadi kelompok sasaran dan membuat } \\
\text { proporsi jumlah sasaran yang sudah mendapatkan layanan terhadap total } \\
\text { kelompok target. }\end{array}$ \\
\hline 3 & Frekuensi & $\begin{array}{l}\text { Seberapa sering kelompok sasaran dapat memperoleh layanan-layanan yang } \\
\text { dijanjikan oleh suatu kebijakan/program. }\end{array}$ \\
\hline 4 & Bias & $\begin{array}{l}\text { Untuk menilai apakah pelayanan yang diberikan oleh implementor bias } \\
\text { (menyimpang) kepada kelompok masyarakat yang bukan menjadi sasaran } \\
\text { program. }\end{array}$ \\
\hline 5 & Ketepatan Layanan & $\begin{array}{l}\text { Untuk menilai apakah pelayanan yang diberikan dalam implementasi } \\
\text { suatu program dilakukan tepat waktu atau tidak. Hal ini penting, jika } \\
\text { keterlambatan dalam implementasi tersebut akan membawa implikasi } \\
\text { kegagalan dalam mencapai tujuan. }\end{array}$ \\
\hline 6 & Akuntabilitas & $\begin{array}{l}\text { Untuk menilai apakah tindakan para implementor dalam menjalankan tugas } \\
\text { mereka untuk menyampaikan keluaran kebijakan kepada kelompok sasaran } \\
\text { dapat dipertanggungjawabkan atau tidak. }\end{array}$ \\
\hline 7 & $\begin{array}{l}\text { Kesesuaian program dengan } \\
\text { kebutuhan target sasaran }\end{array}$ & $\begin{array}{l}\text { Untuk mengukur apakah berbagai keluaran kebijakan atau program yang } \\
\text { diterima oleh kelompok sasaran memang sesuai dengan kebutuhan mereka } \\
\text { atau tidak. }\end{array}$ \\
\hline
\end{tabular}

Sumber: Sidik, 2015

sehingga dapat menemukan hasil temuan baru dan dapat menarik kesimpulan secara umum atas suatu realitas sosial. Secara khusus, metode kualitatif digunakan untuk mengevaluasi suatu program yang bertujuan memberikan gambaran kekuatan dan kelemahan suatu program berdasarkan informasi wawancara subjek penelitian (Patton, 2009), yang dalam hal ini adalah implementasi program Jamkesus Terpadu.

Adapun dalam menentukan informan penelitiannya, peneliti menggunakan teknik purposive sampling dan snowball sampling. Purposive sampling merupakan sampling yang berdasarkan kepada ciri-ciri yang dimiliki oleh subjek yang dipilih karena ciri-ciri tersebut sesuai dengan tujuan penelitian yang akan dilakukan (Herdiansyah, 2012:106). Berdasarkan penggunaan teknik purposive sampling, peneliti memilih informan sesuai dengan kapasitas informasi yang dimiliki melalui pertimbangan bahwa informan tersebut adalah pihak yang paling mengerti dan terkait dengan program Jamkesus Terpadu. Sedangkan penetapan informan masyarakat penyandang disabilitas Kabupaten Gunungkidul dilakukan dengan pertimbangan penyandang disabilitas yang pernah mengakses Jamkesus Terpadu dan mampu untuk berkomunikasi. Teknik snowball juga menjadi teknik yang digunakan untuk melengkapi informan penelitian ini. Snowball sampling adalah teknik pengambilan sampel sumber data, yang pada awalnya jumlahnya sedikit, lama-lama menjadi besar (Sugiyono, 2012:219). Informan satu nantinya memberikan rekomendasi untuk informan selanjutnya kepada peneliti guna mendapatkan informasi yang lebih lengkap.

Pada proses pengambilan data, didapatkan 13 orang yang menjadi informan peneliti. Informan tersebut telah dipilih sesuai dengan kriteria yang telah ditentukan dan sesuai kebutuhan informasi penelitian yang terdiri dari sembilan informan yang dipilih melalui purposive sampling dan empat informan didapatkan melalui snowball sampling. Tiga informan dari instansi Bapel Jamkesos DIY yaitu Ibu Wahyu Widi Astuti selaku Kasi Pelayanan Jaminan Kesehatan, Bapak Agus Priyanto selaku Kasi Kepesertaan dan Pengembangan Program, dan Bapak Suwares selaku Pengelola data dan verifikasi atas rekomendasi Bapak Agus ketika beliau sedang berhalangan untuk ditemui. Dua informan dari instansi Dinas Sosial Kabupaten Gunungkidul, yaitu Bapak Suyatin selaku Kasi Perlindungan Jaminan Sosial, dan Bapak Eko 
Budianto selaku Operator Sistem Informasi Kesejahteraan Sosial atas rekomendasi dari Bapak Suyatin untuk menggantikan beliau sementara karena sedang rapat saat hari $\mathrm{H}$ wawancara.

Sedangkan delapan informan masyarakat penyandang disabilitas Kabupaten Gunungkidul yang pernah mengakses Jamkesus Terpadu, yaitu: a) Bapak Hardiyo (didapatkan pada saat pelaksanaan Jamkesus Terpadu tahun 2020 di Balai Desa Ponjong); b) Bapak Suprihatin, Bapak Sukino, Ibu Sukiyem, Mbak Diana Dwi Lestari, dan Mbak Firda Tindar Pertiwi (didapatkan dari Bapel Jamkesos DIY, yang merupakan data penyandang disabilitas yang mengikuti Jamkesus Terpadu tahun 2020 di Desa Ponjong); c) Mas Andi Joko Prasetyo, dan Bapak Mujiyana (didapatkan dari rekomendasi Bapak Hardiyo). Perlu disampaikan juga bahwa informan penyandang disabilitas tersebut memiliki jenis disabilitas yang berbeda-beda.

Data penelitian dikumpulkan melalui serangkaian wawancara, observasi, dan dokumentasi (Patton, 2009). Wawancara secara langsung dilakukan dengan pihak dari instansi Bapel Jamkesos DIY selaku penyelenggara dan pelaksana JKT, Dinas Sosial Kabupaten Gunungkidul selaku sektor instansi Kabupaten yang bekerja sama dengan Bapel Jamkesos DIY dan berwenang dalam pendataan disabilitas, dan satu penyandang disabilitas. Sebanyak delapan penyandang disabilitas diwawancarai secara berbeda karena pertimbangan kondisi lapangan (pandemi COVID-19). Selain itu, data identitas penyandang disabilitas yang mengakses JKT dari Bapel Jamkesos DIY, seminggu setelah pelaksanaan Jamkesus Terpadu tahun 2020 baru didapatkan pada pertengahan bulan Maret. Tujuh di antara informan tersebut diwawancarai dengan menggunakan media komunikasi melalui video call whatsapp dan telepon, dan hanya satu dilakukan secara tatap muka langsung. Durasi wawancara berlangsung selama 12 hari dan secara berkala. Informasi pokok yang didapatkan adalah keluaran dan hasil program, pelaksanaan kegiatan, dan jejaring kemitraan.

Selain itu, metode observasi non-partisipatif juga digunakan untuk mengamati secara langsung rangkaian kegiatan persiapan hingga pelaksanaan program JKT tahun 2020 di sejumlah tempat, khususnya di Kabupaten Gunungkidul. Proses pengamatan dilakukan ketika menghadiri rapat-rapat persiapan pelaksanaan JKT. Observasi pertama dilakukan pada tanggal 5 Februari 2020 dalam rapat Perencanaan JKT Tahun 2020 di ruang Aula Bapel Jamkesos DIY. Informasi yang diperoleh adalah kebutuhan kepesertaan, proses pelaksanaan, laporan dari setiap kabupaten/kota, dan jadwal pelaksanaan program selama tahun 2020 (lihat Gambar 2).

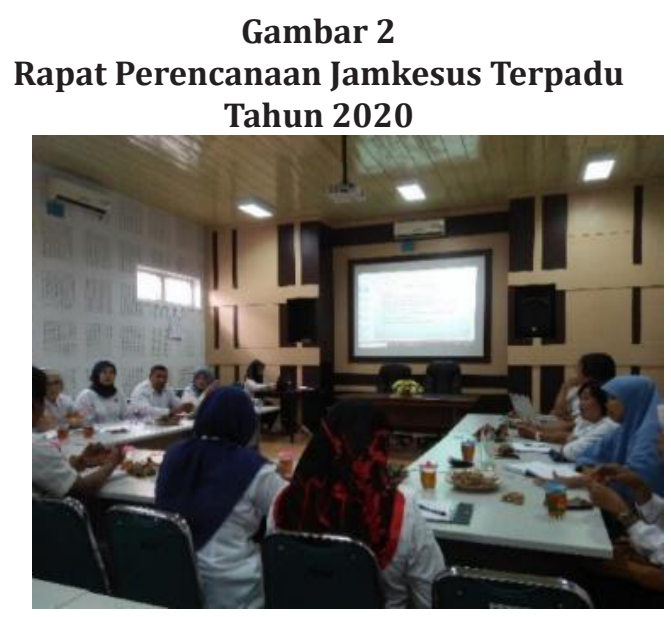

Sumber: Dokumentasi Pribadi, 2020

Observasi dilanjutkan pada tanggal 11 Maret 2020 dengan menghadiri Rapat Persiapan Jamkesus Terpadu di Ponjong Gunungkidul, tepat 1 hari sebelum pelaksanaan JKT. Rapat diadakan di Balai Desa Ponjong yang merupakan tempat penyelenggaraan JKT Gunungkidul tahun 2020. Setelah selesai rapat, diadakan penataan tempat pelaksanaan JKT Gunungkidul oleh pihak Bapel Jamkesos DIY dan perangkat Desa Ponjong (Gambar 3).

\section{Gambar 3}

Rapat Persiapan Jamkesus Terpadu di Ponjong Gunungkidul

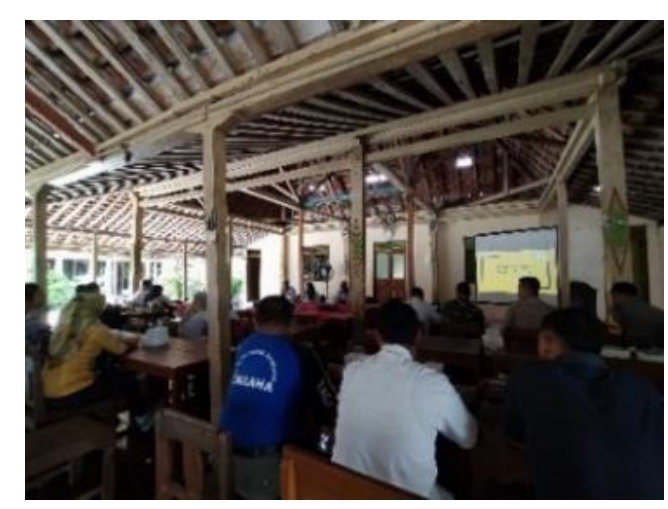

Sumber: Dokumentasi Pribadi, 2020 
Rut Dwi Ardiyantini - Implementasi Program Jaminan Kesehatan Khusus Terpadu dalam Upaya Perlindungan dan Pemenuhan Hak Kesehatan Penyandang Disabilitas

Observasi selanjutnya dilakukan pada saat pelaksanaan JKT Gunungkidul di Balai Desa Ponjong, tanggal 12 Maret 2020. Di lokasi tersebut diamati akses layanan JKT bagi penyandang disabilitas, mekanisme pelayanan, pelayanan yang diberikan, tempat pelayanan, kondisi pelaksanaan JKT, hingga sikap dan perilaku petugas program dan penyandang disabilitas sebagai penerima manfaat. Peneliti membuat catatan lapangan selama pengamatan, juga mendokumentasikan dengan foto dan video pelaksanaan program.

\section{Gambar 4 \\ Pelaksanaan Jamkesus Terpadu Gunungkidul Tahun 2020}



Sumber: Dokumentasi Pribadi, 2020

Data sekunder berupa buku, jurnal, foto, arsip, peraturan nasional dan daerah, profil lembaga pelaksana, dan dokumen lainnya yang berkaitan dengan topik Jamsoskes dikumpulkan melalui metode dokumentasi. Data yang lebih spesifik adalah jaminan kesehatan, Jamkesus Terpadu, perlindungan dan pemenuhan hak kesehatan, penyandang disabilitas, implementasi program dan gambaran wilayah Gunungkidul, termasuk notulensi rapat koordinasi program. Data ini diakses melalui instansi terkait yaitu Bapel Jamkesos, Dinas Sosial Kabupaten Gunungkidul, website Kabupaten Gunungkidul, berita dan media online. Selain itu ada dokumentasi lainnya berupa foto dan video ketika rapat-rapat koordinasi persiapan JKT Gunungkidul, foto para informan penelitian, juga rekaman suara yang peneliti dapatkan ketika wawancara dengan informan.

Proses analisis data secara induktif (Patton, 2009) yang terdiri atas tiga tahapan (Herdiansyah, 2012:164) dilakukan sebagai berikut: data diolah dengan cara memilah, memilih, dan menyederhanakan data serta merangkum butir-butir penting yang relevan dengan fokus penelitian. Reduksi data dilakukan dengan merangkum data yang telah didapat peneliti dari lapangan, dipilah hal-hal yang pokok serta memfokuskan pada hal-hal yang penting sesuai dengan topik dan permasalahan penelitian. Langkah berikutnya adalah menyajikan data dengan cara mengelompokkan data sesuai dengan jenisnya dan diverifikasi satu dengan yang lain guna menarik kesimpulan utama (Miles et al, 2014). Verifikasi bertujuan untuk memeriksa akurasi data kebenaran nyata dari hasil penelitian apakah sesuai kondisi di lapangan. Kesimpulan menjawab implementasi program Jamkesus Terpadu dalam upaya perlindungan dan pemenuhan hak kesehatan bagi penyandang disabilitas.

\section{Hasil}

Fokus bahasan pada penelitian ini adalah Program Jaminan Kesehatan Khusus Terpadu atau yang dikenal juga dengan sebutan JKT. Proses implementasi Jamkesus Terpadu telah berjalan dari tahun 2015 hingga tahun 2020 (Maret), sehingga batasan waktu data dan analisis adalah periode yang sama. Unsur implementasi yang dikaji terdiri dari dua, yakni: pertama, indikator keluaran program yang terdiri dari akses, cakupan, frekuensi, bias, ketepatan layanan, akuntabilitas, dan kesesuaian program dengan kebutuhan target sasaran; dan kedua, indikator hasil program yang terdiri dari dampak langsung, dampak jangka menengah, dan dampak jangka panjang.

\section{Proses Implementasi JKT di Kabupaten Gunungkidul}

Pada proses implementasi program JKT terdapat beberapa tahapan kegiatan yang dijalankan hingga program tersebut sampai kepada penerima manfaat. Peneliti mengikuti rangkaian kegiatan implementasi program JKT di Kabupaten Gunungkidul tahun 2020 untuk menggambarkan proses implementasi program tersebut berjalan. Adapun proses awal yang dilakukan adalah: Pertama, Rapat Perencanaan JKT Tahun 2020 yang diadakan oleh Bapel Jamkesos DIY selaku pihak pelaksana program. Rapat diadakan di ruang Aula Bapel Jamkesos DIY pada tanggal 5 Februari 2020. Tujuan rapat ini adalah untuk membahas perencanaan program selama tahun 2020 yang 
meliputi kebijakan JKT tahun 2020, kebutuhan kepesertaan, proses pelaksanaan, laporan dari setiap kabupaten/kota, dan membuat jadwal bersama untuk pelaksanaan jamkesus terpadu selama tahun 2020 di 5 kabupaten/kota di DIY.

Tahap kedua dilanjutkan dengan Rapat Persiapan JKT di Dinas Sosial Gunungkidul pada tanggal 13 Februari 2020. Berdasarkan data notulensi rapat dari pihak Bapel Jamkesos DIY, rapat tersebut membicarakan mengenai koordinasi dengan pihak-pihak dari Kabupaten Gunungkidul untuk mempersiapkan pelaksanaan program pada tanggal 12 Maret 2020. Ketiga, pelaksanaan sosialisasi JKT kepada masyarakat penyandang disabilitas di Kabupaten Gunungkidul oleh TKSK (Tenaga Kesejahteraan Sosial Kecamatan) selaku pihak dari Dinas Sosial setempat yang berwenang dalam perekrutan peserta program. Sosialisasi dan perekrutan program juga melibatkan organisasi-organisasi disabilitas yang ada di kabupaten, seperti FKDG (Forum Komunikasi Difabel Gunungkidul), PPD (Pusat pemberdayaan Disabilitas) Mitra Sejahtera, dan PPDI (Perkumpulan Penyandang Disabilitas Indonesia) Gunungkidul.

Sehingga dapat disimpulkan di sini bahwa sosialisasi sudah dilaksanakan melalui TKSK dan organisasi disabilitas, namun penyampaian tersebut belum merata kepada penyandang disabilitas, karena rata-rata sosialisasinya melalui grup whatsapp. Penyandang disabilitas juga masih banyak yang belum tercatat dalam kepesertaan program dan belum mengetahui program. Tampaknya sosialisasi secara langsung ke masyarakat penyandang disabilitas itu merupakan salah satu titik lemah dari proses awal implementasi karena informasi yang tidak jelas dan menyeluruh kepada kelompok sasaran dapat mengurangi efektivitas program.

Selanjutnya, keempat, adalah Rapat Internal Persiapan JKT di Bapel Jamkesos DIY pada tanggal 9 Maret 2020. Pada rapat tersebut, pihak Bapel Jamkesos DIY melakukan koordinasi secara internal dengan tujuan untuk membahas persiapan JKT di Gunungkidul yang meliputi pembahasan mengenai pembagian tugas untuk pelaksanaan program, rencana pembahasan rapat persiapan h-1 pelaksanaan JKT Gunungkidul pada tanggal 11 Maret 2020, serta diskusi tentang jaminan dan kepesertaan program. Kelima, Rapat Persiapan JKT di Ponjong Gunungkidul. Rapat dilaksanakan pada tanggal 11 Maret 2020, tepat 1 hari sebelum pelaksanaan JKT, jam 11.00. Rapat diadakan di Balai Desa Ponjong, yang merupakan tempat penyelenggaraan JKT Gunungkidul tahun 2020 yang pertama. Rapat dihadiri oleh berbagai pihak dari kabupaten serta mitra alat bantu yang terlibat dan bekerja sama dengan Bapel Jamkesos DIY dalam JKT, seperti TAGANA (Tanggap Siaga Bencana), Dinas Kesehatan dan Dinas Sosial baik provinsi maupun kabupaten, Koordinatorkoordinator dari organisasi disabilitas, PMI, RSUD, Puskesmas, TKSK, Yakkum, Perangkat Kecamatan dan Desa Ponjong, Kepolisian, TNI, dan sebagainya. Hal yang dibahas adalah agenda pelaksanaan JKT, sarana dan prasarana, data jumlah peserta yang akan mengikuti JKT, pembagian tugas, jadwal penjemputan, dan penataan tempat pelaksanaan.

Keenam, pelaksanaan program JKT Gunungkidul di Balai Desa Ponjong pada tanggal 12 Maret 2020. Lokasi penyelenggaraan JKT berdasarkan pengelompokkan sektor wilayah yaitu utara, timur, selatan, dan barat. JKT yang dilaksanakan ini berada pada sektor timur atau Kecamatan Ponjong yang posisi geografisnya berada di tengah-tengah dari keseluruhan wilayah kecamatan Gunungkidul yang berada di sektor timur (Semin, Ngawen, Ponjong, Semanu, Wonosari, Girisubo, dan Rongkop). Kondisi pelayanan JKT terlihat kondusif dan tempat pelayanan sudah diusahakan ramah bagi para penyandang disabilitas dengan berbagai sarana dan prasarana yang telah disediakan dalam pelaksanaan, seperti kursi roda, kemudian ram-ram untuk bisa dilewati oleh disabilitas ketika melakukan mobilitas untuk mengakses JKT. Tersedia petugas yang mengarahkan alur mekanisme JKT kepada pasien. Pelayanan juga diupayakan tidak diskriminatif bagi penyandang disabilitas. Pelayanan khusus telah disiapkan dan diberikan sesuai dengan kebutuhan para penyandang disabilitas. Semuanya bertujuan agar dapat menciptakan akses pelayanan yang adil dan setara bagi seluruh penyandang disabilitas peserta JKT.

Hal yang menarik adalah dimensi inklusivitas dalam pelayanan, di mana partisipasi organisasi penyandang disabilitas juga turut dilibatkan. Berdasarkan hasil observasi pada rangkaian kegiatan, keterlibatan tersebut terlihat dari awal rapat perencanaan pelaksanaan program dan rapat-rapat yang lain di dalam persiapan pelaksanaan program. Berbagai organisasi tersebut mendapatkan ruang dan kesempatan di 
Rut Dwi Ardiyantini - Implementasi Program Jaminan Kesehatan Khusus Terpadu dalam Upaya Perlindungan dan Pemenuhan Hak Kesehatan Penyandang Disabilitas

dalam memberikan dan menyampaikan aspirasi serta masukan. Selain itu, partisipasi dari para penyandang disabilitas juga dilibatkan dalam pelaksanaan JKT dengan menjadi koordinatorkoordinator yang ikut dalam membantu kegiatan pelayanan. Hal ini menunjukkan adanya pendekatan berbasis hak di mana penyandang disabilitas ditempatkan sebagai objek bukan sebagai subjek.

\section{Keluaran Program JKT}

Analisis keluaran program JKT berfungsi untuk menemukan konsekuensi langsung yang dirasakan oleh penerima manfaat. Hasil analisis keluaran dari implementasi program dilihat dari indikator sebagai berikut:

\section{Aksesibilitas JKT}

Aksesibilitas dalam program JKT tersedia lebih mudah oleh karena strategi yang diterapkan dan berbagai pertimbangan yang dilakukan dalam implementasi program mampu menyediakan sarana dan prasarana bagi kemudahan akses pelayanan untuk penyandang disabilitas. Strategi yang digunakan oleh Bapel Jamkesos DIY dalam mengimplementasikan JKT antara lain berupa jaringan, remote, one stop service, dan terintegrasi. Strategi pertama, membuka jaringan yang luas artinya melakukan kerja sama dengan lintas program dan lintas sektor. Lintas program berupa kerja sama antar satu seksi dengan seksi lainnya yang ada di Bapel Jamkesos DIY. Dalam konteks lintas sektor terdapat Kerjasama antara Dinas Sosial dengan Dinas Kesehatan DIY. Dalam lingkup Kabupaten Gunungkidul berlangsung kerja sama antara instansi pemerintah, seperti BAPPEDA, Bupati, Dinas Sosial (TKSK, Tagana, Pendamping PKH), Dinas Kesehatan, Baznas, RSUD, Rumah Sakit Swasta mitra, Puskesmas, Koramil, Polsek, perangkat Kecamatan, Kelurahan, Desa, organisasi disabilitas, dan lembaga independen, PMI, FKDG, PPDI Gunungkidul, PPD Mitra Sejahtera, dan Karang Taruna. Strategi kedua, mendatangi daerah remote atau daerah-daerah yang jauh dari fasilitas kesehatan. Hal ini ditujukan supaya lebih dekat dengan masyarakat penyandang disabilitas.

Strategi ketiga, dengan konsep one stop service, yaitu menyediakan dan menyatukan berbagai jenis pelayanan dengan sekali datang di satu tempat. Keempat, terintegrasi, artinya ketika semua melaksanakan, semua unsur di sana terintegrasikan, tidak membuat sesuatu yang baru, namun apa yang telah ada dimanfaatkan sebagai bagian dari sistem. Sehingga dapat disimpulkan di sini bahwa strategi yang diterapkan oleh Bapel Jamkesos DIY ini menjadi suatu langkah untuk memaksimalkan implementasi JKT di Kabupaten Gunungkidul. Banyak jaringan yang dibangun dengan para stakeholders untuk mencapai tujuan program dan mewujudkan perlindungan dan pemenuhan hak kesehatan bagi penyandang disabilitas.

\section{Cakupan Sasaran Program yang Dijangkau JKT}

Berdasarkan Peraturan Gubernur Nomor 50 Tahun 2017 pada pasal 3, peserta program JKT meliputi peserta PBI Jamkesus, yaitu penyandang disabilitas yang tergolong fakir miskin atau tidak mampu yang merupakan penduduk DIY yang menerima bantuan pembiayaan berupa iuran yang dibayar secara teratur oleh Pemerintah Daerah DIY kepada Bapel Jamkesos DIY; dan peserta Jaminan Penyangga, yaitu penyandang disabilitas perorangan yang tergolong fakir miskin, tidak mampu, dan/atau Penyandang Masalah Kesejahteraan Sosial yang merupakan penduduk DIY yang belum memiliki jaminan atau tidak memperoleh jaminan kesehatan. Pada indikator cakupan ini akan dijelaskan dalam proporsi jumlah sasaran penyandang disabilitas yang sudah mendapatkan layanan terhadap total peserta yang telah ditargetkan. Data tersebut dipaparkan pada Tabel 2 .

Berdasarkan data pada Tabel 2, tampak bahwa persentase capaian penyandang disabilitas di Kabupaten Gunungkidul yang terjangkau Program JKT cenderung fluktuatif selama periode 2015 hingga 2020 (Maret). Proporsi jumlah sasaran yang mengakses program terhadap total target yang ingin dijangkau menunjukkan bahwa target program pada implementasi JKT di Kabupaten Gunungkidul rata-rata masih belum tercapai, meskipun pernah tercapai dua kali di tahun 2017 dan 2018. Hal tersebut disebabkan oleh berbagai faktor yang membuat perkembangan program Jamkesus Terpadu di Kabupaten Gunungkidul mengalami peningkatan satu kali kemudian menurun terus hingga bulan Maret tahun 2020.

\section{Frekuensi Pelayanan JKT yang Diterima Penyandang Disabilitas \\ Indikator frekuensi pada penelitian ini bertujuan untuk memperlihatkan seberapa sering penyandang disabilitas sebagai kelompok}


Tabel 2

Perbandingan Jumlah Sasaran dan Capaian Cakupan Program Jamkesus Terpadu

\begin{tabular}{|c|c|c|c|c|}
\hline Sasaran & Tahun & Jumlah Sasaran & $\begin{array}{c}\text { Jumlah Capaian } \\
\text { (mengakses) }\end{array}$ & $\begin{array}{c}\text { Persentase } \\
\text { Capaian }\end{array}$ \\
\hline \multirow{6}{*}{$\begin{array}{l}\text { Semua Jenis Penyandang } \\
\text { Disabilitas di Kabupaten } \\
\text { Gunungkidul yang merupakan } \\
\text { PBI Jamkesus atau Penyangga }\end{array}$} & 2015 & 120 & 54 & $45 \%$ \\
\hline & 2016 & $\begin{array}{l}\text { Tidak dilaksanakan } \\
\text { JKT }\end{array}$ & 0 & $0 \%$ \\
\hline & 2017 & 240 & 261 & $109 \%$ \\
\hline & 2018 & 120 & 121 & $101 \%$ \\
\hline & 2019 & 150 & 130 & $87 \%$ \\
\hline & $\begin{array}{c}2020 \\
\text { (Maret) }\end{array}$ & 150 & 83 & $55 \%$ \\
\hline
\end{tabular}

Sumber: Bapel Jamkesos DIY, 2020

sasaran memperoleh layanan dari program Jamkesus Terpadu. Frekuensi program JKT di Kabupaten Gunungkidul ini diukur dari pelaksanaan program yang telah dilaksanakan dari tahun 2015 sampai dengan tahun 2020 pada bulan Maret. Terdapat perbandingan data pelaksanaan JKT di DIY dengan pelaksanaan di Kabupaten Gunungkidul dari tahun 2015 - 2020 (Maret) yang akan dipaparkan dalam Tabel 3.

Tabel 3

Perbandingan Jumlah Pelaksanaan JKT di DIY dan Kabupaten Gunungkidul

\begin{tabular}{cccl}
\hline No. & $\begin{array}{c}\text { Tahun } \\
\text { Pelaksanaan }\end{array}$ & DIY & \multicolumn{1}{c}{$\begin{array}{c}\text { Kabupaten } \\
\text { Gunungkidul }\end{array}$} \\
\hline 1 & 2015 & 2 kali & 1 kali di Wonosari \\
2 & 2016 & 10 kali & Tidak ada pelaksanaan \\
3 & 2017 & 16 kali & 2 kali di Nglipar dan \\
& & & Karangmojo \\
4 & 2018 & 12 kali & 1 kali di Wonosari \\
5 & 2019 & 10 kali & 1 kali di Paliyan \\
6 & 2020 (Maret) & 10 kali & 2 kali di Ponjong dan \\
& & & Gedangsari (Oktober) \\
\hline
\end{tabular}

Sumber: Bapel Jamkesos DIY, 2020

Dari tabel di atas tampak bahwa dengan jumlah pelaksanaan Jamkesus Terpadu di DIY yang telah dilaksanakan untuk kelima kabupaten/ kota, seharusnya rata-rata pelaksanaannya di setiap kabupaten/kota adalah dua kali per tahun. Akan tetapi pelaksanaan JKT di Kabupaten Gunungkidul rata-rata hanya satu kali pada setiap tahun. Jika memperhatikan kondisi di Kabupaten Gunungkidul, seharusnya pemerintah setempat bisa lebih memperhatikan penyandang disabilitas dengan cara melaksanakan lebih dari satu kali program JKT. Namun demikian, fakta di lapangan justru menunjukkan bahwa masih banyak penyandang disabilitas yang membutuhkan bantuan untuk bisa menerima pelayanan kesehatan yang baik, layak, dan merata.

\section{Bias JKT terhadap Sasaran Program}

Bias adalah indikator untuk melihat apakah pelayanan JKT terjadi bias (menyimpang) kepada penyandang disabilitas yang bukan menjadi target sasaran program atau yang tidak sesuai dengan kriteria dan aturan yang telah ditentukan. Berdasarkan data yang diperoleh di lapangan, menunjukkan bahwa program JKT di Kabupaten Gunungkidul belum $100 \%$ tepat sasaran. Guna meminimalisir dan memantau terjadinya ketidaktepatan sasaran pada implementasi program, terdapat beberapa tahapan yang dijalankan, yaitu pengecekan di kelurahan dengan adanya proses verifikasi dan validasi data. Jika ditemukan data-data yang tidak sesuai dan meragukan, Bapel Jamkesos DIY akan melakukan supervisi ke lapangan berupa kunjungan studi kasus. Pemeriksaan kembali di lapangan dilakukan dengan wawancara terhadap peserta yang telah mengakses program, untuk melihat apakah program telah tepat sasaran ataupun sebaliknya. Metode tersebut setidaknya dapat mengurangi bias, meskipun tidak menjamin bahwa seluruh proses dan ketepatan sasaran terpenuhi secara maksimal.

\section{Ketepatan Pemberian Program JKT}

Kriteria ini digunakan untuk menilai apakah pelayanan yang diberikan sudah tepat waktu atau tidak. Hal ini penting, sebab jika terjadi keterlambatan dalam implementasi tersebut maka akan berimplikasi pada tidak efektifnya pencapaian tujuan program. Ketepatan pemberian layanan pada implementasi program ini dipengaruhi oleh tiga faktor yaitu waktu, 
Rut Dwi Ardiyantini - Implementasi Program Jaminan Kesehatan Khusus Terpadu dalam Upaya Perlindungan dan Pemenuhan Hak Kesehatan Penyandang Disabilitas

anggaran, dan sumber daya manusia yang tersedia. Dalam hal ini, data penelitian di lapangan menunjukkan bahwa ketepatan pemberian layanan pada implementasi JKT masih bermasalah dalam hal waktu yang tidak konsisten, kondisi medan yang relatif sulit dijangkau, keterbatasan anggaran, dan keterbatasan sumber daya manusia dari pihak Bapel Jamkesos DIY.

\section{Akuntabilitas Program JKT}

Akuntabilitas berkaitan dengan tindakan para pelaksana di dalam menjalankan tugas untuk menyampaikan luaran kebijakan kepada target sasaran untuk dapat dipertanggungjawabkan. Berdasarkan informasi yang diperoleh dari pihak Bapel Jamkesos DIY, terdapat landasan hukum berupa regulasi yang menjadi dasar pertanggungjawaban dalam implementasi program JKT. Landasan hukumnya adalah Peraturan Gubernur Nomor 87 Tahun 2018, yang menunjuk Bapel Jamkesos DIY untuk menyelenggarakan kegiatan di bidang jaminan kesehatan bagi masyarakat DIY. Landasan hukum untuk pelaksanaan program adalah Peraturan Gubernur Nomor 63 Tahun 2016 tentang Jamkesta, Peraturan Gubernur Nomor 50 tahun 2017 (perubahan dari Nomor 51 tahun 2013) tentang Sistem Penyelenggaraan Jamkesus bagi Disabilitas, Peraturan Gubernur Nomor 51 Tahun 2017 tentang Bantuan Alat Bantu Kesehatan bagi Penyandang Disabilitas, dan Peraturan Gubernur Nomor 21 Tahun 2018 tentang Standar Biaya Layanan dan Biaya Verifikator Jamkesta pada Bapel Jamkesos DIY. Landasan hukum yang ada tersebut telah menunjukkan adanya transparansi secara regulasi pada program JKT. Selain itu terdapat laporan dari program sebagai bentuk pertanggungjawaban dari Bapel Jamkesos DIY sebagai pihak pelaksana program.

Selain itu, transparansi informasi juga telah dilakukan melalui media dan koordinasi dengan berbagai pihak. Meskipun demikian, masih terdapat permasalahan pada penyampaian informasi program yang belum sepenuhnya sampai ke masyarakat, terutama bagi para penyandang disabilitas. Transparansi program tidak cukup jika hanya dilakukan melalui sosialisasi atau pemberitahuan melalui media grup whatsapp dan TKSK saja. Penyampaian informasi oleh TKSK juga dianggap kurang menyasar penerima manfaat secara tepat waktu dan menyeluruh. Hal ini sebagian berkaitan dengan persebaran alamat penerima manfaat secara geografis.

\section{Kesesuaian Program JKT dengan} Kebutuhan Penyandang Disabilitas

Indikator ini digunakan untuk melihat kesesuaian luaran program JKT yang diterima oleh penerima manfaat. Adapun maksud kesesuaian di sini adalah ketepatan antara kebutuhan penerima manfaat dengan layanan yang diberikan melalui JKT. Dalam hal ini, data penelitian menunjukkan bahwa pelayanan JKT relatif sudah sesuai dengan kebutuhan kelompok sasaran program. Hal ini terlihat dari jenis layanan kesehatan berupa pemeriksaan berjenjang mulai dari vital-sign, dokter umum, dokter spesialis, hingga pada pemberian alat bantu yang ada sekitar 106 jenis. Selain itu, pelayanan dan penjaminannya sudah sesuai dengan prosedur dan mekanisme yang ada. Secara umum layanan JKT ini telah membantu bagi penyandang disabilitas.

\section{Hasil Program JKT}

Indikator hasil program digunakan untuk menilai hasil atau dampak implementasi dari program JKT. Hasil atau dampak pada dasarnya berkaitan dengan perubahan kondisi masyarakat yang menjadi kelompok sasaran program, yaitu kondisi awal yang tidak dikehendaki menuju ke kondisi baru yang dikehendaki. Secara umum dapat dikatakan, bahwa program JKT dapat memperbaiki kesulitan penyandang disabilitas miskin untuk mengakses pelayanan kesehatan dan memenuhi kebutuhan kesehatannya.

\section{Dampak Langsung}

Dampak langsung adalah manfaat yang dirasakan langsung oleh penerima manfaat JKT. Manfaat tersebut adalah layanan kesehatan berupa pemeriksaan dokter umum yang memberikan indikasi medis mengenai kondisi tubuh secara umum, kemudian dokter spesialis (KFR dan mata) yang memberikan indikasi medis secara spesifik mengenai kondisi disabilitas, dan obat sesuai indikasi medis yang diberikan oleh dokter. Selain itu penyandang disabilitas yang sesuai kriteria juga mendapatkan ataupun bisa mereparasikan alat bantu sesuai indikasi medis dari dokter spesialis. Layanan kesehatan tersebut semuanya dapat diakses dengan gratis. Terlebih lagi, pun terdapat manfaat lain berupa perlindungan dan pemenuhan hak kesehatan 
yang dirasakan langsung oleh penyandang disabilitas. Dengan demikian, secara spesifik dampak program JKT dapat secara langsung dirasakan oleh penyandang disabilitas miskin di Kabupaten Gunungkidul.

\section{DampakJangka Menengah}

Dampak jangka menengah adalah peningkatan mobilitas bagi penyandang disabilitas. Berdasarkan hasil wawancara dengan delapan informan penyandang disabilitas selaku penerima program, tiga dari delapan diantaranya telah merasakan dampak jangka menengah dari program JKT. Hal ini dikarenakan tiga penyandang disabilitas tersebut (Hardiyo, Andi, dan Mujiyana) pernah mengakses program di tahun-tahun sebelumnya, sedangkan tiga disabilitas lainnya (Suprihatin, Diana, dan Firda) baru mengakses JKT di tahun 2020 ini, sehingga belum menerima distribusi alat bantu yang diberikan karena terkendala dengan adanya pandemi COVID-19. Adapun dua penyandang disabilitas lainnya (Sukino dan Sukiyem) tidak mendapatkan alat bantu melalui JKT karena tidak memenuhi kriteria program. Oleh sebab itu, dampak jangka menengah ini bagi lima penyandang disabilitas tersebut relatif masih belum terwujud. Dengan demikian, dapat disimpulkan bahwa rata-rata penyandang disabilitas mendapatkan alat bantu yang nantinya bisa merasakan dampak jangka menengah dari program JKT, hanya saja belum sepenuhnya bisa dirasakan oleh seluruh penyandang disabilitas.

\section{Dampak Jangka Panjang}

Dampak jangka panjang ini adalah dampak yang ditimbulkan dalam jangka yang panjang atau yang sifatnya seterusnya. Ketika sudah menggunakan alat bantu, penyandang disabilitas diharapkan mampu meningkatkan mobilitas di dalam aktivitas sehari-hari, sehingga produktivitas kerjanya juga ikut meningkat. Hasil akhir dari produktivitas tersebut adalah kemandirian. Kemandirian inilah yang diharapkan akan mengurangi tingkat ketergantungan pada pemerintah. Selain itu, implementasi program JKT juga diharapkan dapat berdampak pada perlindungan dan pemenuhan hak kesehatan disabilitas, yaitu terwujudnya pelayanan kesehatan yang baik dan layak. Program JKT mulai diimplementasikan pada tahun 2015. Lima tahun tersebut belum bisa menunjukkan dampak dalam jangka panjang. Masih perlu waktu untuk melihat hasil akhir seperti diuraikan di atas.

\section{Diskusi}

Catatan Kritis terhadap Implementasi Program JKT

Berdasarkan hasil penelitian tersebut, peneliti kemudian mencoba untuk menganalisis secara kritis pada bagian diskusi ini. Pertama, masih ditemukan fakta bahwa sosialisasi program masih jarang dilakukan dan lebih banyak dilakukan melalui grup whatsapp. Sosialisasi perlu menyentuh semua aspek, baik masyarakat yang menjadi sasaran program maupun masyarakat secara umum. Pemerintah setempatjuga perlu lebih proaktif dan berinisiatif untuk menyosialisasikan program JKT. Hal ini dikarenakan sosialisasi secara langsung kepada masyarakat penyandang disabilitas dengan melibatkan peran pemerintah desa masih terbatas dan seharusnya dapat diatasi dengan jangka waktu yang cukup panjang, bukan secara sporadis. Jika pemerintah desa, misalnya, dilibatkan secara penuh, maka penerima manfaat di sana juga akan lebih terjangkau secara lebih mudah dan merata.

Kedua, masih ada keterbatasan pada penyediaan sarana dan prasarana implementasi program JKT. Program JKT yang merupakan pelayanan penjangkauan ini memerlukan banyak sarana dan prasarana penunjang, antara lain penjemputan penyandang disabilitas yang terhambat oleh keterbatasan moda transportasi. Sejauh ini, sarana penjemputan yang ada menuju tempat pelayanan masih hanya dikhususkan bagi penyandang disabilitas yang tinggal di kecamatan-kecamatan yang menjadi fokus pelayanan JKT. Sehingga pemanfaatan moda transportasi massal juga kiranya dapat diaplikasikan secara menyeluruh untuk memobilisasi penyandang disabilitas pada program tersebut.

Ketiga, frekuensi pelaksanaan program JKT masih terbatas. Dengan rata-rata hanya satu kali dalam setahun, kebutuhan para penerima manfaat jelas tidak terpenuhi. Kondisi wilayah Kabupaten Gunungkidul yang sangat luas merupakan faktor penyebab sulitnya penyandang disabilitas untuk memenuhi kebutuhan dasarnya di bidang kesehatan. Jika, misalnya, dapat dilakukan minimal empat kali dalam setahun, maka kiranya penyandang 
Rut Dwi Ardiyantini - Implementasi Program Jaminan Kesehatan Khusus Terpadu dalam Upaya Perlindungan dan Pemenuhan Hak Kesehatan Penyandang Disabilitas

disabilitas di desa-desa yang masih sulit diakses oleh transportasi umum dapat dilayani. Program JKT memang spesifik dan membutuhkan sumber daya yang tidak sedikit untuk target kuantitatifyang relatif kecil, tetapi hak kesehatan penyandang disabilitas seharusnya tetap menjadi prioritas utama, sama seperti warga negara lainnya secara umum.

\section{Kesimpulan}

Dari tujuh indikator luaran program JKT yang digunakan sebagai pisau analisis pada penelitian ini, terdapat lima indikator yang masih bermasalah, yaitu cakupan sasaran program yang dijangkau, frekuensi pelayanan yang diterima penyandang disabilitas, bias terhadap ketepatan sasaran program, ketepatan pemberian program, dan akuntabilitas program.

Pertama, cakupan sasaran program masih terkendala oleh sejumlah faktor, sehingga target program rata-rata belum tercapai; Kedua, frekuensi pelayanan Jamkesus yang hanya dilaksanakan rata-rata 1 kali tiap tahunnya menyebabkan layanan bagi penyandang disabilitas yang masih kurang merata; Ketiga, walaupun sudah ada upaya untuk meminimalisir dan memantau ketidaktepatan sasaran program, namun bias implementasi Jamkesus Terpadu tidak bisa diminimalkan hingga 100\%; Keempat, masih terdapat beberapa faktor yang membuat ketepatan implementasi program menjadi terhambat; Kelima, meskipun sudah ada landasan hukum dan laporan yang bisa dipertanggungjawabkan, namun informasi program masih kurang transparan.

Hasil program JKT menunjukkan bahwa pelayanan kesehatan berupa pemeriksaan dan pemberian bantuan alat bantu yang diberikan kepada penyandang disabilitas di Kabupaten Gunungkidul berdampak langsung bagi penerima manfaat. Dampak jangka menengah program menunjukkan bahwa rata-rata penyandang disabilitas mendapatkan alat bantu yang nantinya bisa merasakan dampaknya. Namun demikian, hal itu belum sepenuhnya bisa dirasakan oleh penyandang disabilitas di Kabupaten Gunungkidul. Selanjutnya secara jangka panjang dampak ini masih menjadi harapan besar.

Walaupun masih menghadapi sejumlah kendala, implementasi program JKT ini tetap memiliki sisi positif, yaitu pemerintah telah mengupayakan perlindungan dan pemenuhan hak kesehatan bagi penyandang disabilitas melalui pemberian dan pelaksanaan Jamkesus Terpadu. Program ini mampu mewujudkan perlindungan dalam bentuk pemberian jaminan berupa pelayanan kesehatan bagi masyarakat penyandang disabilitas miskin. Perlindungan dalam pelayanan tersebut juga tercermin dari konsep one stop service pada program, pelayanannya gratis, dan akomodasi dan fasilitas antar jemput. Pemenuhan hak kesehatan penyandang disabilitas tercermin dari layanan kesehatan berupa pemeriksaan kesehatan melalui dokter umum dan dokter spesialis, pemberian obat, dan pemberian bantuan alat bantu.

\section{Acknowledgement}

Artikel ini dikembangkan dari Skripsi penulis di Departemen Pembangunan Sosial dan Kesejahteraan (PSdK), Fakultas Ilmu Sosial dan Ilmu Politik, Universitas Gadjah Mada pada tahun 2020.

\section{Referensi}

Azwar, A. (1996). Pengantar Administrasi Kesehatan. Jakarta: Binarupa Aksara.

Bapel Jamkesos DIY. (2020). Rapat Perencanaan Jamkesus Terpadu Tahun 2020 di Bapel Jamkesos DIY. Ppt: tidak dipublikasikan.

Bapel Jamkesos DIY. (2020). Data Target Sasaran dan Jumlah Penyandang Disabilitas yang Mengakses Program Jamkesus Terpadu. Data tidak dipublikasikan.

BPS. (2016). Profil Penduduk Indonesia Hasil Supas 2015. Hlm 75. https:// www.bps. go.id/ publication / 2016/ diakses pada 12 September 2019.

BPS Kabupaten Gunungkidul. (2019). Statistik Daerah Kabupaten Gunungkidul Tahun 2019. https://gunungkidulkab.bps.go.id / publication diakses pada 15 Juni 2020.

Creswell, J. W. (2012). Research Design: Pendekatan Kualitatif, Kuantitatif, dan Mixed (terj.). Yogyakarta: Pustaka Pelajar.

Dinas Sosial DIY. (2019). Data PMKS Disabilitas Tahun 2018. http://dinsos.jogjaprov. go.id/?wpdmpro =data-pmks-disabilitastahun-2018 diakses pada 12 September 2019.

Dodi, A. K. (2012). Pelaksanaan Program Evaluasi Diri Sekolah (EDS) di Smp Negeri 2 Tempel. Skripsi S1 Filsafat dan Sosiologi Pendidikan, UNY. 
Herdiansyah, H. (2012). Metodologi Penelitian Kualitatif untuk Ilmu-Ilmu Sosial. Jakarta: Salemba Humanika.

Kementerian PAN dan RB. (2017). Top 99 Inovasi Pelayanan Publik Indonesia 2017. https:// rb.bps.go.id/CIrbbps/assets/pdf/2017\%20 Buku_TOP_99_2017.pdf diakses pada 18 September 2019.

Kusdiyanto, Y. (2018). Penyandang Disabilitas Punya Hak Sama dalam Pelayanan Kesehatan. Harianjogja.com https://jogjapolitan.harianjogja.com/ read / $2018 / 12 / 05 / 514 / 957089 /$ penyandang-disabilitas-punya-hak-samadalampelayanan-kese hatan diakses pada 4 September 2019.

Miles, M. B., Huberman, A. M., Saldana, J. (2014). Qualitative data analysis: a method. New York: Sage.

Mulyadi, D. (2015). Studi Kebijakan Publik dan Pelayanan Publik, Konsep dan Aplikasi Proses Kebijakan Publik Berbasis Analisis Bukti untuk Pelayanan Publik. Bandung: PT Alfabeta.

Patton, M. Q. (2009). Metode Evaluasi Kualitatif (terj.). Yogyakarta: Pustaka Pelajar.
Peraturan Daerah Provinsi DIY Nomor 4 Tahun 2012 tentang Perlindungan dan Pemenuhan Hak-Hak Penyandang Disabilitas. Pasal 55 ayat 2 dan 3 .

Ripley, R. B. (1985). Policy Analysis in Political Science. Chicago: Nelson-Hall Inc.

Sidik, F. (2015). Implementasi Program Jaminan Pendidikan Daerah di Kota Yogyakarta. Jurnal Kebijakan dan Administrasi Publik, 19(1), pp. 27-42.

Solider. (2018). Layanan Jamkesus Terpadu untuk Lima Kecamatan di Gunungkidul. https://www.solider.id/baca/4777layanan-jamkesus-terpadu-lima-kecamatangunung-kidul diakses pada 10 Juli 2020.

Sugiyono. (2012). Metode Penelitian Kuantitatif, Kualitatifdan R\&D. Bandung: Alfabeta.

Undang-Undang No. 40 Tahun 2004 tentang Sistem Jaminan Sosial Nasional.

Widiyanto, A. (2016). Implementasi Jaminan Kesehatan Khusus (Jamkesus) sebagai Salah Satu Upaya Pemenuhan dan Perlindungan. http://bappeda.jogjaprov. go.id/artikel/ detail/49-implementasija minan-kesehatankhusus-jamkesussebagai-salah-satu-upayapemenuhan-dan-perlindungan diakses pada 4 September 2019. 